\title{
PERP wt Allele
}

National Cancer Institute

\section{Source}

National Cancer Institute. PERP wt Allele. NCI Thesaurus. Code C94767.

Human PERP wild-type allele is located in the vicinity of $6 q 24$ and is approximately $19 \mathrm{~kb}$ in length. This allele, which encodes p53 apoptosis effector related to PMP-22 protein, plays a role in the regulation of both apoptosis and desmosome assembly. Genetic deletion may be associated with tumor formation and metastasis. 